\title{
Use of a single-injection tissue-sampling technique to study steroid uptake by the decidualized endometrium of the mouse
}

\author{
C. Edwards and S. R. Milligan \\ Department of Physiology, King's College, Strand, London, WC2R 2LS, U.K.
}

\begin{abstract}
Summary. A tissue-sampling paired-tracer method was used to investigate the effect of plasma proteins on uptake by the decidualized endometrium of $\left[{ }^{3} \mathrm{H}\right]$ progesterone, $\left[{ }^{3} \mathrm{H}\right]$ oestradiol and $\left[{ }^{3} \mathrm{H}\right]$ corticosterone. When injected arterially in protein-free Ringer, the extraction of progesterone and oestradiol was $100 \%$, while that of corticosterone was only $60 \%$. The addition of $4 \%$ albumin or injection in mouse plasma resulted in significant decreases in progesterone extraction to about $80 \%$ and $65 \%$ respectively. Injection in pregnant guinea-pig plasma reduced progesterone extraction further (to $33 \%$ ). While neither $4 \%$ albumin nor mouse plasma had any significant effect on the uptake of oestradiol, neonatal rat plasma reduced oestradiol extraction to $40 \%$. These results are consistent with high-affinity binding proteins having a limiting effect on the availability of steroids to target tissues.
\end{abstract}

Keywords: mouse; uterus; decidua; steroid-uptake; plasma proteins

\section{Introduction}

Although the endocrine signals, timing and morphological events in early pregnancy are well known, our understanding of the physiological changes within the uterine tissues is still rather poor. Major metabolic changes in uterine tissues do occur in response to oestradiol treatment (e.g. increased RNA, DNA and protein synthesis, amino acid and nucleotide uptake, and glucose oxidation) and accompany decidualization (changes in cell size, degree of polyploidy, glycogen and lipid accumulation, steroid receptor content and enzyme activity), but attempts to characterize the changes in transport of materials into uterine cells and tissues have largely been limited to a few studies on isolated uteri or isolated uterine cells (Noall \& Allen, 1961; Roskoski \& Steiner, 1967; Meier \& Garner, 1984). Such in-vitro studies have the disadvantage that the dynamic state of uterine tissues may render the cells particularly susceptible to specific and non-specific alterations in their function (including the induction of decidualization) both during the mechanical/enzymic cell separation procedures and during incubation.

The single-injection tissue sampling method for measuring the uptake of a test molecule compared to a freely diffusible reference was first developed by Oldendorf (1970) for the rat brain. Since then it has been applied to a number of organs, e.g. rat liver (Pardridge \& Jefferson, 1975; Pardridge, 1977) and uterus of the ovariectomized rat (Laufer et al., 1983; Verheugen et al., 1984).

In the present study, the single-pass tissue-sampling method was developed to investigate uptake by the decidualized uterus of the mouse, and used to study the effects of plasma proteins on the uptake of sex steroids. This extends the previous studies of steroid uptake in the rat uterus (Laufer et al., 1983; Verheugen et al., 1984), brain and liver (Pardridge \& Mietus, 1979a, b).

\section{Materials and Methods}

Animals. Adult Swiss albino mice (A. Tuck and Son Ltd, Battlebridge, Essex, U.K.) weighing $25-35 \mathrm{~g}$ were fed a pellet diet (41 B Oxoid) and tap water ad libitum and were housed at $21^{\circ} \mathrm{C}$ with lights on from 06:00 to 18:00 h. Ovariectomy was 
performed under ether anaesthesia via a small dorsal incision at least 10 days before use. Hormones were administered by subcutaneous injection in $100 \mu \mathrm{l}$ arachis oil (British Drug Houses Ltd, Poole, Dorset, U.K.).

Mice were primed with $100 \mathrm{ng}$ oestradiol- $17 \beta$ for 3 days followed by 3 days with no treatment and 3 days of $1 \mathrm{mg}$ progesterone with $10 \mathrm{ng}$ oestradiol-17 3 . This produces maximal sensitivity to a decidual stimulus 3-6 h after the last hormone injection (Finn \& Martin, 1972). Under ether anaesthesia, a decidual cell reaction was induced in the left uterine horn by injecting, with a 25 -gauge needle, $10 \mu \mathrm{l}$ arachis oil intraluminally into the anterior tip. On the following day, mice received $1 \mathrm{mg}$ medroxyprogesterone acetate. These procedures resulted in the development of a large deciduoma in the instilled horn 4 days after oil instillation.

The radioactive compounds ${ }^{3} \mathrm{H}_{2} \mathrm{O},\left[{ }^{3} \mathrm{H}\right]$ inulin (mol. wt 5200), ${ }^{3} \mathrm{H}$-labelled steroids, D- $\left[{ }^{14} \mathrm{C}\right]$ mannitol and ${ }^{125} \mathrm{I}$ labelled human serum albumin were purchased from Amersham International Ltd (Amersham, Bucks, U.K.) and $\left[{ }^{14} \mathrm{C}\right]$ butanol and carboxy[ $\left.{ }^{14} \mathrm{C}\right]$ dextran (mol. wt $50000-70000$ ) from New England Nuclear (Dreieich, West Germany). Bovine serum albumin (globulin free), steroids and activated charcoal were obtained from Sigma London Chemical Co. (Poole, Dorset, U.K.). Dextran-coated charcoal (500 mg activated charcoal with $50 \mathrm{mg}$ Dextran T70 (Pharmacia, Uppsala, Sweden) in $500 \mu \mathrm{l}$ phosphate-buffered saline) was used to remove endogenous steroids from some plasma samples: $100 \mu \mathrm{l}$ dextran-coated charcoal were added per $\mathrm{ml}$ plasma, incubated at $37^{\circ} \mathrm{C}$ for $30 \mathrm{~min}$ (Wingfield et al., 1984) and then centrifuged, leaving a steroid-free supernatant.

Measurement of uterine uptake. The tissue-sampling single-pass method measures the uptake of a test molecule from the vasculature into a particular organ (Oldendorf, 1970). It involves injection of a radiolabelled test molecule together with a 'freely diffusible' reference molecule into an artery perfusing the organ being studied. After a single pass of the injected bolus through the vasculature of the tissue, the ratio of test molecule to reference remaining in the tissue is determined. This ratio can be compared with that in the injectate and the uptake index of the test molecule calculated from the equation:

$$
\text { Uptake index }=\frac{\text { (d.p.m. test molecule/d.p.m. reference) tissue }}{\text { (d.p.m. testmolecule/d.p.m. reference) injectate }} \times 100 \%
$$

Groups of 5-11 mice bearing a decidual reaction in the left uterine horn were anaesthetized with $0 \cdot 2-0 \cdot 3 \mathrm{ml}$ tribromoethanol $(80 \mathrm{mg} / \mathrm{ml}$ ) injected intraperitoneally (East Anglia Chemicals Ltd, Ipswich, Suffolk, U.K.). The left femoral artery was exposed without damaging the body wall and the major blood vessels branching from the external iliac artery to the body wall were ligated. The femoral artery was cannulated with a 30-gauge needle. This allowed the rapid, retrograde injection of a $50 \mu \mathrm{l}$ bolus using a Harvard infusion pump (model no. 906A) set to deliver at a rate of $950 \mu \mathrm{l} / \mathrm{min}$. The injection took $\sim 3 \mathrm{sec}$ and no mixing of the injectate with blood was observed in the external iliac artery. All timings were made from the end of the injection. The injectate contained $1.5-2 \cdot 5 \mu \mathrm{Ci}^{3} \mathrm{H}$ and $0.5 \mu \mathrm{Ci}^{14} \mathrm{C}$ of the appropriate reference and test molecules.

The anaesthetized mice were killed by transection below the level of the heart to ensure immediate cessation of blood flow through the uterine vasculature. The whole decidualized horn, or decidual tissue isolated from the myometrium by rapid dissection of the frozen tissue (Edwards \& Milligan, 1987), was dissected out, weighed and solubilized with Soluene-100 (Packard, Downers Grove, IL, U.S.A.). The d.p.m./horn and in the $50 \mu l$ injection mixture samples were determined for ${ }^{14} \mathrm{C}$ and ${ }^{3} \mathrm{H}$ using a Packard $460 \mathrm{C}$ liquid scintillation counter with quench and background correction.

Experiment 1. To calculate the uterine uptake index of a test solute compared with a freely diffusible reference using the tissue sampling method, it is necessary to ensure that the organ is sampled after the injected bolus has passed across the uterine vasculature only once. To follow the time course of the bolus through the uterine vasculature, the uptake indices of the large molecular weight compounds $\left[{ }^{3} \mathrm{H}\right]$ inulin and $\left[{ }^{14} \mathrm{C}\right]$ dextran were compared with those of the freely diffusible reference molecules $\left[{ }^{14} \mathrm{C}\right]$ butanol and ${ }^{3} \mathrm{H}_{2} \mathrm{O}$ respectively (Pardridge \& Mietus, 1979a; Oldendorf \& Braun, 1976). $\left[{ }^{3} \mathrm{H}\right]$ Inulin was injected in $0.9 \%(\mathrm{w} / \mathrm{v}) \mathrm{NaCl}$ and $\left[{ }^{14} \mathrm{C}\right]$ dextran in buffered Ringer $(147 \mathrm{mM}-\mathrm{NaCl}, 4 \mathrm{mM}$ $\mathrm{KCl}, 2 \mathrm{~mm}-\mathrm{CaCl}_{2}, 5 \mathrm{~mm}$-Hepes, $\mathrm{pH} 7 \cdot 4$ ). Mice were killed 2, 5, 10, 15 and $20 \mathrm{sec}$ after injection and the uptake indices determined.

Experiment 2. The vascular supply to the mouse uterus is derived from the caudal uterine artery and the cranial utero-ovarian artery. To determine the relative extent to which parts of the uterus are perfused by the $50 \mu$ l bolus injected into the femoral artery, $2.5 \mu \mathrm{Ci}^{3} \mathrm{H}_{2} \mathrm{O}$ were injected and the animals killed $15 \mathrm{sec}$ later. The uterine horn was removed and cut transversely into 4 approximately equal parts (numbered 1 to 4 ; ovarian to cervical region of the uterine horn). Each segment was weighed and the d.p.m./g wet weight was expressed as a percentage of the total d.p.m./g in the whole horn. The proportion of the injected bolus which perfused the uterus was calculated for each horn according to the equation:

$$
\text { injectate perfusing the uterus }(\%)=\frac{{ }^{3} \mathrm{H} \mathrm{d.p.m.} \mathrm{(recovered} \mathrm{in} \mathrm{uterus)}}{{ }^{3} \mathrm{H} \text { d.p.m. (injected bolus) }} \times 100 \%
$$

Experiment 3. When a freely diffusible reference tracer is used in the single-pass tissue-sampling method, the assumption is made that it is completely taken up by the organ on a single pass through the vasculature with negligible backflux from the organ to the blood. This has been shown not to be the case, however, for $\left[{ }^{14} \mathrm{C}\right]$ butanol in the rat uterus (Laufer et al., 1983) and brain (Pardridge et al., 1980), or for ${ }^{3} \mathrm{H}_{2} \mathrm{O}$ in the rat liver (Pardridge, 1977). Butanol retained in the rat uterus $15 \mathrm{sec}$ after injection into the aorta was estimated to be only $77 \%$ of the maximum extracted at $0 \mathrm{sec}$ (Laufer et al., 1983). Determination of the reference extraction at the time when the animal is killed (Er) allows 
calculation of net extraction of the test molecule $(E t)$ from its uptake index $(E t=$ uptake index $\times \mathrm{Er})$. This extraction value is still limited by the assumption that backflux of the test molecule is zero.

$\left[{ }^{14} \mathrm{C}\right]$ Butanol $(0.5 \mu \mathrm{Ci})$ or ${ }^{3} \mathrm{H}_{2} \mathrm{O}(2.5 \mu \mathrm{Ci})$ were injected in buffered Ringer, and animals were killed $0.5,1$ or $2 \mathrm{~min}$ later. The radioactivity remaining in the whole uterus or the separated endometrium was determined after weighing. For each reference, the intercept at $0 \mathrm{~min}$ of a plot of natural $\log$ d.p.m./mg $v s$ time gives the maximal extraction of reference. All other values of d.p.m./mg were expressed as a percentage of this maximal extraction. The slopes of the plots of natural log percentage maximum extraction $v$ s time (Fig. 2) are the rate constants of reference efflux from the tissue (k).

Experiment 4. It became apparent that even fairly large molecules (e.g. inulin, mol. wt 5200) were able to cross the capillary membrane relatively easily and rapidly entered the uterus after arterial injection of a single bolus. To determine the potential for uptake into the extracellular space (ECS), the extractions of $\left[{ }^{14} \mathrm{C}\right]$ mannitol and $\mathrm{L}-\left[{ }^{14} \mathrm{C}\right]$ glucose $(\mathrm{ECS}$ markers) were determined $15 \mathrm{sec}$ after injection $\left({ }^{3} \mathrm{H}_{2} \mathrm{O}\right.$ for reference). Decidualized endometrium from only the cervical half of the uterine horn was used.

Experiment 5. To study the effect of plasma proteins on uterine uptake of progesterone, oestradiol and corticosterone, their uptake indices for the decidual tissue in the cervical half of the uterus were determined $15 \mathrm{sec}$ after injection. Steroids $(1 \cdot 25-2.5 \mu \mathrm{Ci})$, with $0.5 \mu \mathrm{Ci}\left[{ }^{14} \mathrm{C}\right]$ butanol as reference, were injected at a concentration of $300 \mathrm{nM}$ (progesterone), $550 \mathrm{nM}$ (oestradiol-173) or $500 \mathrm{nM}$ (corticosterone) in a variety of media, including Ringer, Ringer with $4 \%$ BSA, Ringer with $8 \%$ BSA, ovariectomized mouse plasma, pregnant (Day 16-20) mouse plasma, pregnant mouse plasma which had been incubated with dextran-coated charcoal to remove endogenous steroids, pregnant (Day 50-60) guinea-pig plasma, and neonatal (1-3 days old) rat plasma. All solutions were made up at least $30 \mathrm{~min}$ before use. To investigate whether progesterone uptake was saturable, the extraction of labelled progesterone in Ringer was determined with $25 \mu \mathrm{M}$ unlabelled progesterone added. All uptake indices were converted to uterine extraction.

Physiological concentrations of progesterone and oestradiol from Days 4 to 12 of mouse pregnancy are $100 \mathrm{nM}$ and $70 \mathrm{pM}$ respectively (McCormack \& Greenwald, 1974), and that of corticosterone in male mice varies diurnally between 50 and $300 \mathrm{nM}$ (McGillis et al., 1983). Although the concentrations used in the present study were higher than the physiological levels, they were necessary to obtain sufficient d.p.m. per sample. It is unlikely that these higher concentrations affected uptake index determinations and when progesterone was injected in ovariectomized mouse plasma at concentrations of 75,300 and $600 \mathrm{nM}$, progesterone extraction was $74.3 \pm 3 \%, 68 \pm 6 \%$ and $81 \pm 7 \%$ respectively $(\mathrm{F}(2,17)=1.984, P>0 \cdot 05)$.

Statistical analyses. Data were analysed using Student's $t$ test, or one-way analysis of variance and Duncan's new multiple range test $(\mathrm{Li}, 1957)$ as appropriate. Means were expressed as mean \pm s.e.m.

\section{Results}

\section{Experiment 1: time course of a single pass through the vasculature of decidualized uterine horn}

The uptake indices of inulin and dextran had decreased markedly by $15 \mathrm{sec}$ (Fig. 1), suggesting that the injected bolus had been largely cleared from the uterus by this time. Subsequent uptake studies were therefore performed with tissue sampling $15 \mathrm{sec}$ after injection. The uptake index of dextran was lower than that of inulin at $2 \mathrm{sec}(t=5.609$, d.f. $=16, P<0.001)$ and $15 \mathrm{sec}$ $(t=7 \cdot 361$, d.f. $=14, P<0 \cdot 001)$.

\section{Experiment 2: distribution of injected ${ }^{3} \mathrm{H}_{2} \mathrm{O}$ along the length of the uterine horn after femoral arterial injection}

The recovery of ${ }^{3} \mathrm{H}_{2} \mathrm{O}$ from the uterus was $16 \cdot 4 \pm 2 \cdot 1 \%$ of the total injected. The amount in the two upper (ovarian) quarters of the uterus (segments 1 and $2: 12 \cdot 7 \pm 2.9 \%, 22 \cdot 5 \pm 4 \cdot 1 \%$ respectively) was significantly $(P<0.05)$ less than that in the lower (cervical) half (segments 3 and $4: 35 \cdot 7 \pm 3 \cdot 7 \%, 29 \cdot 1 \pm 4 \cdot 5 \%$ respectively)

\section{Experiment 3: butanol and water efflux from the decidualized uterus and uterine endometrium}

Efflux of the reference molecules from the whole uterus and separated endometrium are shown in Fig. 2. Extraction of $\left[{ }^{14} \mathrm{C}\right]$ butanol by the endometrium at $15 \mathrm{sec}$ was $84 \cdot 3 \%$, while that of ${ }^{3} \mathrm{H}_{2} \mathrm{O}$ was $84.7 \%$. The efflux constant in the endometrium was $-0.6865 \mathrm{~min}^{-1}$ for $\left[{ }^{14} \mathrm{C}\right]$ butanol and $-0.6654 \mathrm{~min}^{-1}$ for ${ }^{3} \mathrm{H}_{2} \mathrm{O}$. For the whole uterus, extraction of butanol was $79.9 \%$ at $15 \mathrm{sec}$ (Fig. 2) and the butanol efflux constant was $-0.9063 \mathrm{~min}^{-1}$. 


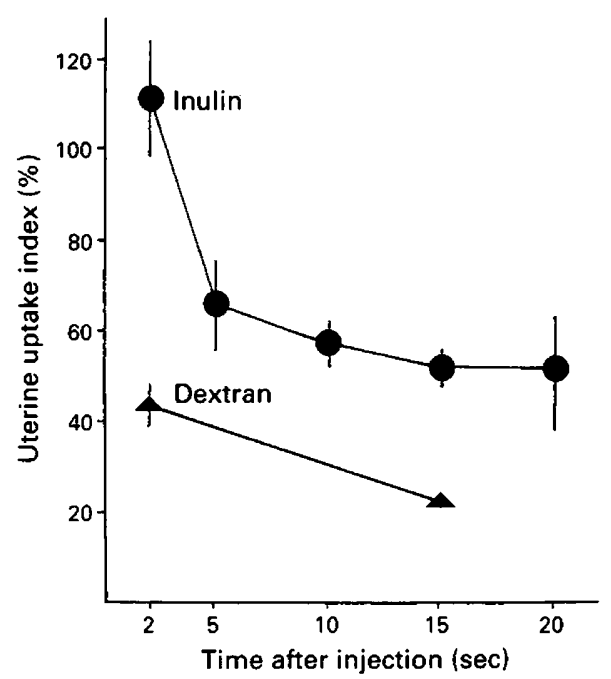

Fig. 1. Mice were injected via the left femoral artery with $\left[{ }^{3} \mathrm{H}\right]$ inulin and $\left[{ }^{14} \mathrm{C}\right]$ butanol, or $\left[{ }^{14} \mathrm{C}\right]$ dextran and ${ }^{3} \mathrm{H}_{2} \mathrm{O}$. They were killed at various times after injection and the uterine uptake indexes of $\left[{ }^{3} \mathrm{H}\right]$ inulin $(\Theta)$ and $\left[{ }^{14} \mathrm{C}\right] \operatorname{dextran}(\Delta)$ were determined in the decidualized left uterine horn. Values are means \pm s.e.m. for 5-11 mice.

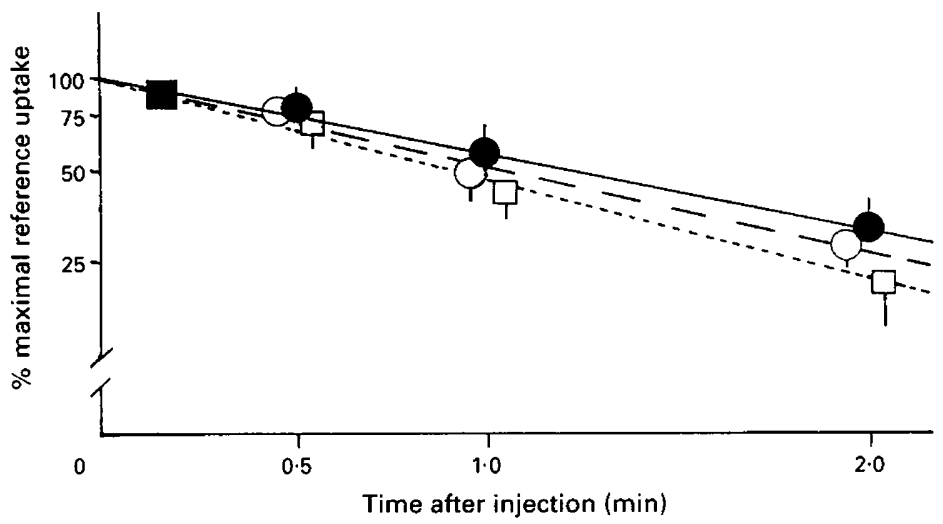

Fig. 2. Mice were injected via the left femoral artery with ${ }^{3} \mathrm{H}_{2} \mathrm{O}$ (closed symbols) or $\left[{ }^{14} \mathrm{C}\right]$ butanol (open symbols). They were killed at various times after injection to study the uptake and retention of reference material by the decidualized endometrium $(\Theta, O)$ and whole uterus $(\square, \square)$. Values are means \pm s.e.m. for $6-9$ mice.

\section{Experiment 4: uptake of extracellular space markers}

The uptake indices of mannitol and L-glucose in the decidualized uterine endometrium were $76 \pm 5 \%$ and $67 \pm 6 \%$, respectively $(t=1 \cdot 102$, d.f. $=15, P>0.05)$, with extractions of $65 \pm 5 \%$ and $56 \pm 5 \%$. The uptake index of mannitol was significantly greater than that obtained for inulin in $\operatorname{Exp} .1(t=2.997$, d.f. $=14, P<0.05)$. 

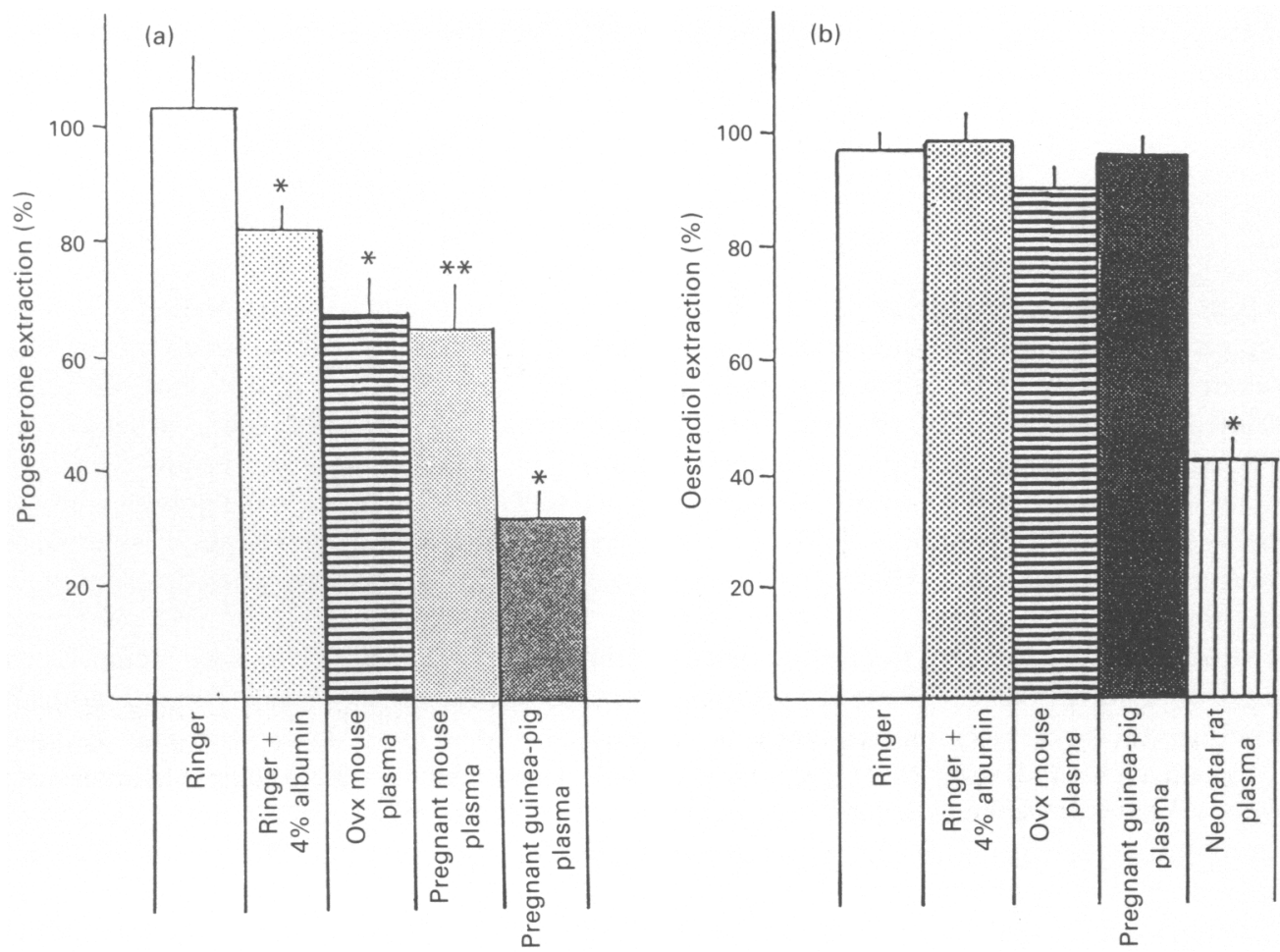

Fig. 3. The extractions of (a) $\left[{ }^{3} \mathrm{H}\right]$ progesterone and (b) $\left[{ }^{3} \mathrm{H}\right]$ oestradiol were determined in the decidualized endometrium of the mouse $15 \mathrm{sec}$ after injection into the femoral artery. The steroids were injected in a $50-\mu \mathrm{l}$ bolus of Ringer or plasma, with $\left[{ }^{14} \mathrm{C}\right]$ butanol as the reference material. Values are means \pm s.e.m. for $6-13$ mice. (a) ${ }^{*} P<0.05$, compared with Ringer; ${ }^{* *} P<0.05$, compared with Ringer $+4 \%$ albumin; $\nmid P<0.01$, compared with all other treatments. (b) ${ }^{*} P<0.01$, compared with all other treatments.

\section{Experiment 5: effect of plasma proteins on steroid uptake by the decidualized uterine endometrium}

In the absence of plasma proteins, extraction of progesterone and oestradiol was about $100 \%$ (Fig. 3). The addition of $25 \mu \mathrm{M}$ unlabelled progesterone to the injectate had no effect on progesterone uptake (extraction in Ringer $=103 \pm 9 \%$; with $25 \mu \mathrm{M}$-progesterone $=101 \pm 10 \%$ ). Plasma proteins had a marked effect on the extraction of progesterone by the decidualized tissue (Fig. 3): $4 \%$ albumin added to Ringer caused a $20 \%$ decrease in the extraction of progesterone $(P<0 \cdot 05)$. No significant difference in progesterone extraction was observed after injection in Ringer containing $4 \%$ albumin $(80 \pm 7 \%)$ or $8 \%$ albumin $(78 \pm 6 \%)(t=0.152$, d.f. $=14, P>0.05)$. Injection of progesterone in plasma from ovariectomized or pregnant mice caused a further decrease in progesterone uptake compared with the value for $4 \%$ albumin $(t=2 \cdot 168$, d.f. $=19, P<0 \cdot 05 ; t=2 \cdot 187$, d.f. $=17, P<0.05$, respectively). There was no significant difference between uterine extraction of progesterone when injected in untreated pregnant mouse plasma $(65 \pm 8 \%)$ or pregnant mouse plasma from which the endogenous steroids had been removed $(74 \pm 5 \% ; t=0.906$, d.f. $=10$, $P>0.05)$. Pregnant guinea-pig plasma markedly reduced progesterone extraction below that obtained with albumin or plasma $(P<0.01)$.

By contrast, oestradiol extraction by the decidualized endometrium was not significantly affected by albumin, or mouse or guinea-pig plasma. Neonatal rat plasma, however, caused the extraction of oestradiol to decrease by about $50 \%$ compared with any other treatment $(\mathrm{F}(4,34)=46 \cdot 5, P<0 \cdot 01)$. 
Extraction of corticosterone in Ringer $(60 \pm 3 \%)$ was lower than that of progesterone or oestradiol, and neither $4 \%$ albumin nor plasma from ovariectomized mice had any significant effect $(64 \pm 6 \%, 54 \pm 5 \%$, respectively).

\section{Discussion}

This paper reports the development and validation of a quick and simple in-situ method of studying the uptake of labelled tracers in the decidualized uterus of the mouse. It allows investigation of the uterus in a relatively undisturbed state and has the particular advantage that it does not require invasion of the body wall. This contrasts with the studies of Laufer et al. (1983) and Verheugen et al. (1984), who made injections into the abdominal aorta. The relatively poor perfusion of the upper (ovarian) half of the uterus by the $50 \mu \mathrm{l}$ intrafemoral arterially injected bolus in the present study was probably due to the contribution of the ovarian artery to the uterine vascular supply. To avoid this complication, only the cervical half of the decidualized uterine horn was used when determining the extraction of test compounds.

Extraction of butanol by the decidualized endometrium at $15 \mathrm{sec}(83 \%)$ was similar to that reported by Laufer et al. (1983) in the uterus of the ovariectomized rat $(77 \%)$. The butanol efflux constant for the whole decidualized uterus of the mouse $\left(-0.906 \mathrm{~min}^{-1}\right)$ was similar to that in the ovariectomized rat $\left(-1.05 \mathrm{~min}^{-1}\right.$; Laufer et al., 1983), although efflux from the endometrium was lower $\left(-0.686 \mathrm{~min}^{-1}\right)$. Knowledge of the reference efflux characteristics allows net extraction of a test molecule to be calculated and extractions by different organs and in different species can be compared.

The high uptake $(50 \%)$ of inulin (mol. wt 5200 ) into the decidualized uterus suggests that this molecule is not a suitable vascular space marker in this organ, even after a single pass. This is in contrast with the low uptake index of inulin in the brain (about 1.5\%) (Oldendorf, 1970), but is consistent with the fact that the high uterine vascular permeability to albumin is further increased during decidual development (Milligan \& Mirembe, 1985). In the rat liver, inulin uptake at $15 \mathrm{sec}$ was about $20 \%$ (Pardridge \& Jefferson, 1975), suggesting that the decidualized uterus is even more permeable than this organ. Nevertheless, the uterine uptake index of inulin was smaller than that of the extracellular space marker mannitol, suggesting that inulin uptake was still restricted to some extent. The considerably lower retention of dextran than inulin in the present study suggests that much of the dextran is rapidly washed out of the uterine vasculature without being extracted.

The ability of an organ to sequestrate ovarian steroids depends not only on the serum concentration, but also on the presence of plasma proteins (Siiteri et al., 1982), capillary membrane permeability to the steroid (Pardridge \& Mietus, 1979b) and capillary transit time for the organ (Pardridge \& Mietus, 1979a). Only about 1-3\% of gonadal steroid hormones exist in the free state in vivo (Burke \& Anderson, 1972), the remainder being bound to albumin (which exhibits low affinity, high capacity binding), or to more specific, high-affinity low-capacity binding globulins. When injected in Ringer alone, the uptake of progesterone and oestradiol (100\%) by the decidualized endometrium was not limited by permeability barriers. Similar findings have been reported for the ovariectomized rat uterus (Laufer et al., 1983), intact rat brain (Pardridge \& Mietus, 1979b; Pardridge et al., 1980) and liver (Pardridge \& Mietus, 1979a). Since progesterone uptake was not saturable in the present study, unbound progesterone probably enters by simple diffusion. The lower extraction of corticosterone suggests that permeability may be a limiting factor in the uptake of this hormone, possibly reflecting its more polar nature. Similar findings have been reported for the ovariectomized rat uterus (Laufer et al., 1983) and rat brain (Pardridge \& Mietus, 1979b).

The addition of albumin to the injected bolus reduced the extraction of progesterone to $82 \%$, but had no effect on the extraction of oestradiol. Since this extraction of progesterone and oestradiol markedly exceeded the concentration that exists as free steroid (1-3\%) in $2-5 \%$ solutions of albumin (Rosenthal et al., 1969), steroid extraction by the uterus cannot be limited only to the free 
steroid fraction. It is likely that during its passage through the uterine vasculature, albumin-bound progesterone dissociates and can then be extracted as free hormone.

It was not surprising that mouse plasma had little effect on oestradiol extraction by the decidualized endometrium, since the plasma of adult mice does not contain sex hormone-binding globulin (Pardridge \& Mietus, 1979a). However, mouse plasma did produce a further small decrease in progesterone extraction, suggesting that other progesterone-binding molecules may be present. Although a possible candidate here would be corticosteroid-binding globulin (MacLaughlin et al., 1972), late pregnant mouse plasma, which contains a high concentration of corticosteroid-binding globulin (Gala \& Westphal, 1967), failed to decrease progesterone extraction any further.

Binding of steroids to high-affinity plasma proteins may not only protect them from metabolism in the peripheral circulation (Siiteri et al., 1982), but may also be important in limiting their extraction by target organs. The results of this study clearly show that the presence of specific binding proteins significantly limits the uptake of progesterone and oestradiol by the uterus. Pregnant guinea-pig plasma, which contains a high-affinity binding globulin (MacLaughlin et al., 1972), reduced progesterone extraction to about $30 \%$ and neonatal rat plasma, which contains a specific highaffinity oestrogen binding protein (Raynaud et al., 1971), reduced oestradiol extraction to $40 \%$. These results suggest that the dissociation of steroids from high-affinity binding proteins is a limiting factor in the uptake of steroids into target tissue (Pardridge \& Mietus, 1979a; Laufer et al., 1983). While specific binding globulins limit the uptake of steroids by the uterus, it is still possible that some of the protein-steroid complex may be extracted in its undissociated state. Up to $50 \%$ of corticosteroidbinding globulin in man is extravascular (Sandberg et al., 1964), and sex hormone-binding globulin has been located in cells of the reproductive tract of male monkeys (Bordin \& Petra, 1980).

This study was supported by grants from the Wellcome Trust and the Medical Research Council.

\section{References}

Bordin, S. \& Petra, P.H. (1980) Immunocytochemical localization of the sex steroid-binding protein of plasma in tissues of the adult monkey Macaca nemestrina. Proc. natn. Acad. Sci. U.S.A. 77, 5678-5682.

Burke, C.W. \& Anderson, D.C. (1972) Sex hormonebinding globulin is an oestrogen amplifier. Nature, Lond. 240, $38-40$.

Edwards, C. \& Milligan, S.R. (1987) Uterine blood flow during the development and regression of the decidual cell reaction in ovariectomized, steroid-treated mice. J. Reprod. Fert. 81, 515-532.

Finn, C.A. \& Martin, L. (1972) Endocrine control of the timing of endometrial sensitivity to a decidual stimulus. Biol. Reprod. 7, 82-86.

Gala, R.R. \& Westphal, U. (1967) Corticosteroid binding activity in serum of mouse, rabbit and guinea pig during pregnancy and lactation: possible involvement in the initiation of lactation. Acta endocr., Copenh. $55,47-61$.

Laufer, L.R., Gambone, J.C., Chaudhuri, G., Pardridge, W.M. \& Judd, H.L. (1983) The effect of membrane permeability and binding by human serum proteins on sex steroid influx into the uterus. J. clin. Endocr. Metab. 56, 1282-1287.

Li, J.C.R. (1957) Introduction to Statistical Inference. Edward Brothers, Ann Arbor.

MacLaughlin, D.T., Harding, G.B. \& Westphal, U. (1972) Steroid protein interactions. XXV. Binding of progesterone and cortisol in pregnancy sera: progesterone-binding globulin and uterine cytosol receptor in the pregnant guinea pig. Am. J. Anat. 135, 179-186.

McCormack, J.T. \& Greenwald, G.S. (1974) Progesterone and oestradiol-17 $\beta$ concentrations in the peripheral plasma during pregnancy in the mouse. J. Endocr. 62, 101-107.

McGillis, J.P., Hall, N.R. \& Goldstein, A.L. (1983) Circadian rhythm of thymosin- $\alpha 1$ in normal and thymectomized mice. J. Immun. 131, 148-151.

Meier, D.A. \& Garner, C.W. (1984) Characterization of the glucose transport system in uterine plasma membranes. Biol. Reprod. 30 (Suppl. 1), 182, Abstr.

Milligan, S.R. \& Mirembe, F.M. (1985) Intraluminally injected oil induces changes in vascular permeability in the 'sensitized' and 'non-sensitized' uterus of the mouse. J. Reprod. Fert. 74, 95-104.

Noall, M.W. \& Allen, W.M. (1961) Early stimulation by estradiol of amino acid penetration in rabbit uterus. J. biol. Chem. 236, 2987-2990.

Oldendorf, W.H. (1970) Measurement of brain uptake of radiolabeled substances using a tritiated water internal standard. Brain Res. 24, 372-376.

Oldendorf, W.H. \& Braun, L.D. (1976) $\left[{ }^{3}\right.$ H]tryptamine and ${ }^{3} \mathrm{H}$-water as diffusible internal standards for measuring brain extraction of radio-labeled substances following carotid injection. Brain Res. 113, 219-224. 
Pardridge, W.M.(1977) Unidirectional influx of glutamine and other neutral amino acids into liver of fed and fasted rat in vivo. Am. J. Physiol. 232, E492-496.

Pardridge, W.M. \& Jefferson, L.S. (1975) Liver uptake of amino acids and carbohydrates during a single circulatory passage. Am. J. Physiol. 228, 1155-1161.

Pardridge, W.M. \& Mietus, L.J. (1979a) Transport of steroid hormones through the rat blood-brain barrier. Primary role of albumin-bound hormone. J. clin. Invest. 64, 145-154.

Pardridge, W.M. \& Mietus, L.J. (1979b) Transport of protein-bound steroid hormones into liver in vivo. Am. J. Physiol. 237, E367-372.

Pardridge, W.M., Moeller, T.L., Mietus, L.J. \& Oldendorf, W.H. (1980) Blood-brain barrier transport and brain sequestration of steroid hormones. Am. J. Physiol. 239, E96-102.

Raynaud, J.P., Mercier-Bodard, C. \& Baulieu, E.E. (1971) Rat estradiol binding plasma protein (EBP). Steroids 18, 767-788.

Rosenthal, H.E., Slaunwhite, W.R. \& Sandberg, A.A. (1969) Transcortin: a corticosteroid-binding protein of plasma. X. Cortisol and progesterone interplay and unbound levels of these steroids in pregnancy. $J$. clin. Endocr. Metab. 29, 352-367.
Roskoski, R. \& Steiner, D.F. (1967) The effect of estrogen on sugar transport in the rat uterus. Biochim. biophys. Acta 135, 717-726.

Sandberg, A.A., Woodruff, M., Rosenthal, H., Nienhouse, S. \& Slaunwhite, W.R. (1964) Transcortin: A corticosteroid-binding protein of plasma. VII. Halflife in normal and estrogen-treated subjects. $J$. clin. Invest. 43, 461-466.

Siiteri, P.K., Murai, J.T., Hammond, G.L., Nisker, J.A., Raymoure, W.J. \& Kuhn, R.W. (1982) The serum transport of steroid hormones. Recent Prog. Horm. Res. 38, 457-510.

Verheugen, C., Pardridge, W.M., Judd, H.L. \& Chaudhuri, G. (1984) Differential permeability of uterine and liver vascular beds to estrogens and estrogen conjugates. J. clin. Endocr. Metab. 59, 1128-1132.

Wingfield, J.C., Matt, K.S. \& Farner, D.S. (1984) Physiologic properties of steroid hormone binding proteins in avian blood. Gen. comp. Endocr. 53, 281-292. 